\title{
Populations analysis of the Brazilian Sharpnose Shark Rhizoprionodon lalandii (Chondrichthyes: Carcharhinidae) on the São Paulo coast, Southern Brazil: inferences from mt DNA sequences
}

\author{
Fernando Fernandes Mendonça ${ }^{1}$, Claudio Oliveira ${ }^{1}$, Otto Bismarck Fazzano Gadig ${ }^{2}$ \\ and Fausto Foresti ${ }^{1}$
}

\begin{abstract}
Sharks of the genus Rhizoprionodon can be considered some of the most important predators along the trophic coastal marine ecosystems and represent an important economic resource for the small-scale fisheries, especially on the Brazilian coastline. In order to analyze the population structure of the shark Rhizoprionodon lalandii of São Paulo, Southeastern coast of Brazil, levels of genetic diversity were identified by nucleotide sequence analyses of the mitochondrial DNA control region. The results obtained from this study present moderate values of haplotype diversity and low nucleotide diversity. Although the AMOVA tests $\left(\Phi_{\mathrm{ST}}=0.08394, \mathrm{P}<0.01\right)$ had shown slightly differences among the studied samples, evidence for the occurrence of population structuring was not found, which may be a general feature of sharks living in coastal areas.

Tubarões do gênero Rhizoprionodon são considerados predadores de grande importância ao longo da cadeia trófica nos ecossistemas costeiros e marinhos, também representando um importante recurso econômico para a pesca, especialmente no litoral brasileiro. A fim de analisar a estrutura populacional do tubarão Rhizoprionodon lalandii no litoral de São Paulo, sudeste do Brasil, foram identificados os níveis de diversidade genética a partir da análise de sequências nucleotídicas da região controladora do DNA mitocondrial. Os dados obtidos neste estudo apresentam valores moderados de diversidade haplotípica e baixos índices de diversidade nucleotídica. Embora os testes de AMOVA $\left(\Phi_{\mathrm{ST}}=0,08394, \mathrm{P}<0,01\right)$ tenham revelado uma pequena diferença entre as amostras estudadas, evidências sobre a ocorrência de estruturação populacional não foram encontradas o que pode representar uma característica geral para tubarões vivendo em áreas costeiras.
\end{abstract}

Key words: D-loop, Haplotypes, Mitochondrial control region, Shark conservation.

\section{Introduction}

Fishery resources are considerably important for the maintenance of the ecosystems and of significant value as food. Although the exploitation of sharks and rays for eating, medical, and religious purposes has been practiced since the 16th century, a significant increase in its capture has been observed (Stone et al., 1998). Statistical data from FAO (Food and Agriculture Organization of the United Nations) show that the total world capture of sharks and rays corresponded to 823,844 and 828,364 tons in 1999 and 2000, respectively. From this total, Brazil was responsible for 2.25\% (18,553 t) in 1999 and 2.23\% (18,480 t) in 2000 (FAO, 2002). However, 31,300 tons of sharks and rays were captured in Brazil in the 1980's decade, a period that represented the golden years of the elasmobranch fishery in the country (Bonfil, 1994). Unfortunately, there is a lack of recent statistical data in Brazil, and an up-to-date prospect of the fishery situation in the country is not available.

The worldwide management of elasmobranch stocks has been impaired by the lack of basic information on their population dynamics. The available data on Brazilian coast sharks are restricted to few species that can be also found on the Red List of Threatened Species of the IUCN (International Union for the Conservation of Nature and Natural Resources) (Camhi et al., 1998).

The sharks of the genus Rhizoprionodon have a worldwide range, usually associated with coastal areas, however few studies about these fish were published (Sadowsky, 1967; Lessa, 1986; Kasim, 1991; Grace \& Henwood, 1997) and some species of the genus Rhizoprionodon are included on the IUCN

\footnotetext{
${ }^{1}$ Laboratório de Biologia e Genética de Peixes, Departamento de Morfologia, Instituto de Biociências de Botucatu, Universidade Estadual Paulista - UNESP, Distrito de Rubião Júnior, s/n, 18618-000 Botucatu, SP, Brazil. fernandofm@ibb.unesp.br

${ }^{2}$ Campus Experimental do Litoral Paulista, Universidade Estadual Paulista - UNESP, Praça Infante D. Henrique, s/n, 11330-900 São Vicente, SP, Brazil.
} 
Red List of Threatened Species (www.iucn.org, 2006).

The Brazilian sharpnose shark Rhizoprionodon lalandii is a small size species that belongs to the family Carcharhinidae, which occurs in the Atlantic Ocean, from Panama to Argentina (Figueiredo, 1977; Compagno, 1984). Due to its abundance and occurrence on the coastal waters, it plays an important role as a predator in the marine coastal ecosystem, and constitutes an important economic resource for the small-scale fisheries. In Brazil, this species is qualified by the IUCN as vulnerable. Fishing of elasmobranches has systematically increased on the coast of the State of São Paulo since 1996 (Gadig et al., 2002). According to Motta et al. (2005), R. lalandii is the most captured shark species, representing $60 \%$ of all sharks caught in this region.

The number of expressive studies about the genetic structure of sharks and rays populations along the Brazilian coast is quite reduced, contrasting with the increasing number of elasmobranches captured, the continued inclusion of new species as endangered or at risk of extinction, and the lack of appropriate knowledge for the sustainable management of these exploited species. Thus, the aim of the present study was to search information that can support the establishment and characterization of the population structure of the Brazilian sharpnose shark, Rhizoprionodon lalandii, on the São Paulo coast, Southern Brazil, as well as offer support management strategies for the sustainable exploitation of this species.

\section{Material and Methods}

Samples characterization. Samples of Rhizoprionodon lalandii were obtained from local fishermen communities, sampled, and identified and vouchers were kept in the fish collection of Laboratório de Biologia e Genética de Peixes (LBP), Departamento de Morfologia, Instituto de Biociências, UNESP, Botucatu, São Paulo, Brazil. Thirty-five samples (13 neonates, 14 juveniles and

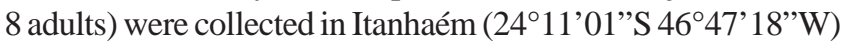
(voucher number: LBP 3001), 22 samples (10 neonates and 12 juveniles) in Praia Grande, (2400’35”S 46²4’45”'W) (voucher number: LBP 3154), and 37 samples (16 neonates, 11 juveniles

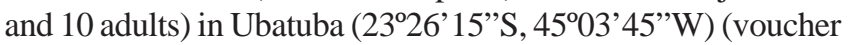
number: LBP3006), all of them in the State of São Paulo, Brazil, between March and December 2005.

DNA extraction, amplification by PCR, and nucleotide sequencing. Total genomic DNA was extracted from the branchial tissue, using the phenol/chloroform protocol, according to Sambrook \& Russel (2001). The amplification of the D-Loop mitochondrial segment (1300 bp) was achieved by Polymerase chain reaction (PCR). The amplification reaction included $25 \mu \mathrm{l}$ of solution containing $0.8 \mathrm{mM}$ of dNTP, $1.5 \mathrm{mM}$ of $\mathrm{MgCl}_{2}, 1 \mathrm{x}$ buffer reaction (20 mM Tris-HCl pH 8.4, and $50 \mathrm{mM} \mathrm{KCl}$ ), $100 \mathrm{ng}$ of primers ( $\mathrm{F}$ - 5' CTC CCAAAG CCA AGATTCTG - 3' and R 5'-GGC TTAGCAAGG TGTCTTCTT GG - 3') according to Cao (1998) and 1 unit of enzyme Taq DNA Polymerase (Invitrogen). Each round consisted of 35 PCR cycles. Each cycle consisted of denaturation at $95^{\circ} \mathrm{C}$ for 1 minute, annealing at $55^{\circ} \mathrm{C}$ for 30 seconds, and 1 -minute extension at $72^{\circ} \mathrm{C}$. The amplified segments of DNA were visualized on $1 \%$ agarose gel stained with Ethidium Bromide. Purified sequencing reactions were electrophoresed in denaturing polyacrylamide gels on an ABI PRISM 377 DNA sequencer.

Data Analyses. Mitochondrial Control region sequences were aligned using the program DAMBE (Xia, 2001) and checked by eye. The nucleotide composition, sequence diversity, number of polymorphic sites, number of transitions and transversions, haplotype diversity, and haplotype number were calculated using ARLEQUIN version 3.01 (Excoffier \& Schneider, 2005). Analyses of molecular variance (AMOVA) (Excoffier et al., 1992) were conducted to examine spatial genetic heterogeneity among nurseries for both control region haplotypes, using ARLEQUIN 3.01. Significance of $\Phi$ statistics was determined via nonparametric permutation (Excoffier et al., 1992), with 1000 data permutations.

\section{Results}

Although the PCR amplification of the D-Loop mtDNA generated a fragment of approximately $1300 \mathrm{bp}$, the nucleotide sequence was determined for a segment of $514 \mathrm{bp}$ of the most variable region (5' extremity), which was composed of 32.48\% adenine, $37.18 \%$ thiamine, $20.48 \%$ cytosine, and $9.86 \%$ guanine. The prevalence of a higher AT content was evidenced in the control region of the mitochondrial DNA in the species Rhizoprionodon lalandii. Twenty one sites were variables, resulting in 16 haplotypes (Table 1 ) with values of haplotype diversity, 0.8239 , and nucleotide diversity, 0.004843 \pm 0.002941 , calculated according to Nei (1987).

Haplotypes 1, 2, 3, 6, 10, 11, 14, and 16 were found in 83 samples, which involves $88.3 \%$ of the analyzed sharks. Regarding these, 34 were sampled on the Ubatuba, 30 on the Itanhaém, and 21 on Praia Grande coast. The other original haplotypes were distributed among the three areas without repetitions (Table 2). Three well-represented haplotypes were noticed within the haplotype network (Fig. 1): H1, H2, and H3. It is worth highlighting that no separation in groups of geographic samples was observed, and that the most representative haplotypes are found in all three localities. However, the analysis of molecular variance showed a value corresponding to a moderate structuring among populations $\left(\Phi_{\mathrm{ST}}=0.08394, \mathrm{P}<\right.$ $0.01)$, among populations within groups $\left(\Phi_{\mathrm{SC}}=0.05487, \mathrm{P}<0.01\right)$, and among groups $\left(\Phi_{\mathrm{CT}}=0.03076, \mathrm{P}<0.01\right)$.

\section{Discussion}

Our results suggest moderate values of haplotypes diversity, low nucleotide diversity and a high degree of gene flow among samples of Brazilian sharpnose shark collected on the São Paulo Coast. However, a moderate structuring was observed among populations, among populations within groups, and among groups. These results are similar to those found by Heist et al. (1996) with the species Rhizoprionodon terranovae on the U.S.A Atlantic coast and in the western 
Table 1. Polymorphic nucleotide positions for Brazilian sharpnose shark Rhizoprionodon lalandii haplotypes. Different haplotypes are listed in the left column and the positions of polymorphic base pairs are listed across the top row. The nucleotide at each position is given for haplotype 1. Only nucleotides different from haplotype 1 are given for all other haplotypes. Nucleotides identical to haplotype 1 are indicated with periods (.) and deletions are indicated with dashes (-).

\begin{tabular}{|c|c|c|c|c|c|c|c|c|c|c|c|c|c|c|c|c|c|c|c|c|c|}
\hline \multirow[b]{4}{*}{ Haplotypes } & \multicolumn{21}{|c|}{ Nucleotide Position } \\
\hline & & & & 1 & 1 & 1 & 2 & 2 & 2 & 3 & 3 & 4 & 4 & 4 & 4 & 4 & 4 & 4 & 4 & 4 & 5 \\
\hline & 5 & 6 & 6 & 3 & 5 & 9 & 4 & 4 & 5 & 9 & 9 & 1 & 2 & 3 & 5 & 5 & 5 & 6 & 8 & 9 & 1 \\
\hline & 2 & 0 & 1 & 4 & 0 & 5 & 2 & 7 & 7 & 6 & 8 & 7 & 2 & 5 & 4 & 7 & 9 & 8 & 7 & 0 & 2 \\
\hline 1 & $\mathrm{~A}$ & $\mathrm{~T}$ & $\mathrm{~A}$ & $G$ & A & $\mathrm{T}$ & $\mathrm{C}$ & $\mathrm{C}$ & $\mathrm{T}$ & $\mathrm{A}$ & - & $\mathrm{T}$ & $\mathrm{C}$ & - & $\mathrm{T}$ & - & $\mathrm{T}$ & $G$ & - & $\mathrm{C}$ & $\mathrm{G}$ \\
\hline 2 & . & . & . & A & . & . & $\mathrm{T}$ & . & . & . & . & . & . & . & . & . & . & A & . & . & . \\
\hline 3 & . & . & . & . & . & . & $\mathrm{T}$ & . & . & . & . & . & . & . & . & . & . & . & . & . & . \\
\hline 4 & . & $\mathrm{C}$ & . & A & . & . & $\mathrm{T}$ & . & . & . & . & . & . & . & . & . & . & . & . & . & \\
\hline 5 & . & . & . & A & . & . & $\mathrm{T}$ & . & . & . & . & . & G & . & . & . & . & . & . & . & \\
\hline 6 & . & . & . & A & . & $\mathrm{C}$ & $\mathrm{T}$ & . & $\mathrm{C}$ & . & . & . & . & . & . & . & . & A & $\mathrm{C}$ & - & \\
\hline 7 & . & . & . & A & . & . & $\mathrm{T}$ & . & . & . & . & . & . & . & . & . & . & . & . & . & . \\
\hline 8 & $\mathrm{~T}$ & . & . & . & . & . & $\mathrm{T}$ & . & . & . & . & . & . & . & . & . & . & . & . & . & . \\
\hline 9 & . & . & . & . & $\mathrm{T}$ & . & $\mathrm{T}$ & . & . & . & . & - & . & C & . & . & . & . & . & . & . \\
\hline 10 & . & . & . & A & . & . & $\mathrm{T}$ & . & C & . & . & . & . & . & . & . & . & A & $\mathrm{C}$ & . & . \\
\hline 11 & . & . & . & . & . & . & $\mathrm{T}$ & . & . & & . & . & . & . & . & . & . & A & . & . & . \\
\hline 12 & . & . & $\mathrm{C}$ & A & . & . & $\mathrm{T}$ & $\mathrm{T}$ & $\mathrm{C}$ & $\mathrm{T}$ & $\mathrm{T}$ & . & . & . & . & . & . & A & $\mathrm{C}$ & . & A \\
\hline 13 & . & . & . & A & . & . & $\mathrm{T}$ & . & $\mathrm{C}$ & . & . & . & . & . & $\mathrm{C}$ & $\mathrm{G}$ & . & A & C & - & \\
\hline 14 & . & . & . & . & . & . & . & . & . & . & . & . & . & . & . & . & . & A & . & . & . \\
\hline 15 & . & . & . & . & . & C & $\mathrm{T}$ & . & . & . & . & . & . & . & . & . & C & A & . & . & . \\
\hline 16 & . & . & . & A & . & . & $\mathrm{T}$ & $\mathrm{T}$ & C & . & . & . & . & . & . & . & & A & C & - & \\
\hline
\end{tabular}

Table 2. Geographic distribution of Brazilian sharpnose shark Rhizoprionodon lalandii mtDNA control region haplotypes. The numbers of samples according to geographic sites are indicated in parenthesis. Dashes indicate haplotypes not found.

\begin{tabular}{lcccccccccccccccc}
\hline & \multicolumn{11}{c}{ Haplotypes } \\
\hline Sample Site & 1 & 2 & 3 & 4 & 5 & 6 & 7 & 8 & 9 & 10 & 11 & 12 & 13 & 14 & 15 & 16 \\
Ubatuba (37) & 1 & 9 & 14 & - & - & - & - & - & - & 3 & 5 & 1 & 1 & 2 & 1 & - \\
Itanhaém (35) & 14 & 2 & 11 & 1 & 1 & 3 & 1 & 1 & 1 & - & - & - & - & - & - & - \\
Praia Grande (22) & 10 & 4 & 1 & - & - & - & - & - & - & - & 3 & - & - & - & - & 4 \\
Total & 25 & 15 & 26 & 1 & 1 & 3 & 1 & 1 & 1 & 3 & 8 & 1 & 1 & 2 & 1 & 4 \\
\hline
\end{tabular}

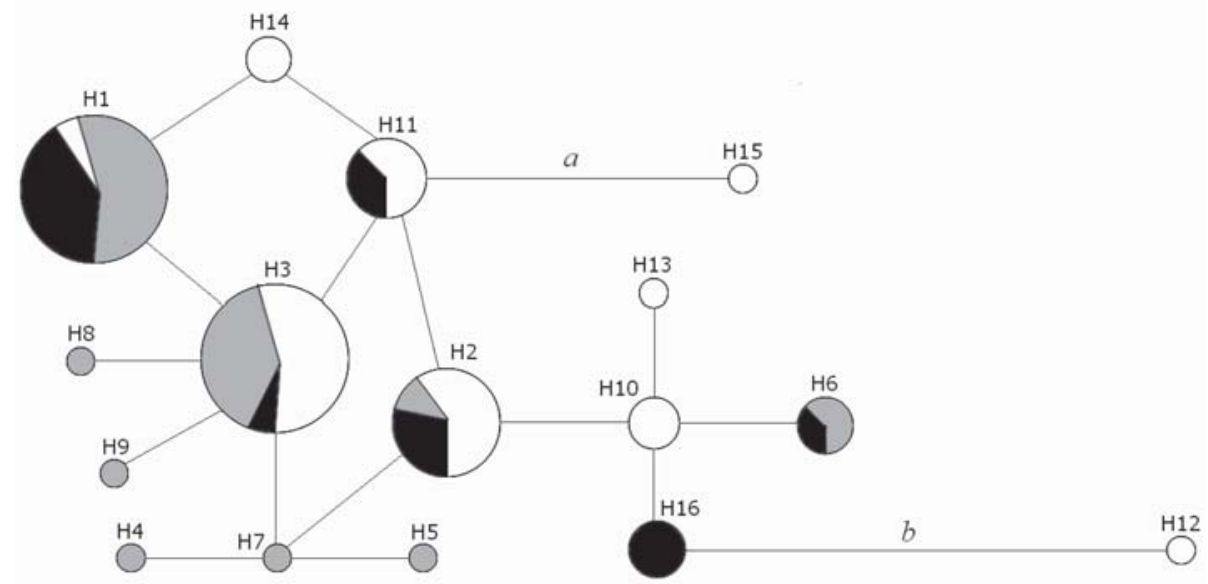

Fig. 1. Median-joining haplotype network. The haplotypes are represented by circles, with the width proportional to their frequencies. Black circles correspond to Praia Grande, white to Ubatuba, and gray to Itanhaém samples. Each branch corresponds to a single mutation, except line $a$ (with 2 mutations) and line $b$ (with 3 mutations).

Gulf of Mexico. In the cited paper, the most common haplotype was found with similar frequencies in each sample and in each year among the Atlantic samples (range $=0.50-0.67$ ). The haplotype diversity among samples was 0.694 , indicating that, historically, there has been sufficient gene flow among sharpnose sharks from the Gulf of Mexico to the Mid-Atlantic Bight preventing significant divergence in mitochondrial DNA haplotypes. Although additional investigations should be conducted before a more general hypothesis is proposed, these results allow us to suggest that sharks of the genus
Rhizoprionodon may have only a weak populational structure in relatively wide coastal areas, as observed in the present study and by Heist et al. (1996).

This observation may also be true for other shark species as Carcharhinus plumbeus for which Heist et al. (1995) studying populations from the Gulf of Mexico and MidAtlantic Bight also found low levels of genetic variability. The nucleotide diversity was very low (0.161) with 87 of 95 individuals sharing the common genotype.

On the other hand, studies conducted in more wide areas 
indicate that other shark species have populations strongly structured, as was observed for Carcharias taurus $\left(\Phi_{\mathrm{ST}}=0.295\right.$; $\mathrm{P}<0.001$ ), showing an insignificant migration between the eastern and western Australia and southern Africa (Stow et al., 2006). A strong structuring (mitochondrial $\Phi_{\mathrm{ST}}=0.350, \mathrm{P}<0.001$; nuclear $\Phi_{\mathrm{ST}}=0.007, \mathrm{P}<0.001$ ) was also reported for Carcharias limbatus caught between the northwestern Atlantic, Gulf of Mexico, and Caribbean Sea (Kenney et al., 2005) and for the hammerhead shark (Sphyrna lewini) from different ocean population subdivisions (overall $\Phi_{\mathrm{ST}}=0.749, \mathrm{P}<0.0001$ and among oceans $\left.\Phi_{\mathrm{ST}}=0.598, \mathrm{P}<0.0098\right)$. In these cases, genetic discontinuity within oceans $\left(\Phi_{\mathrm{ST}}=0.519, \mathrm{P}<0.0001\right)$ was primarily associated with oceanic barriers (Duncan et al., 2006).

Therefore, it is possible to conclude that there is a tendency for low population structure or even for an absence of population structure among shark samples from restricted areas and moderate to high population structuring among shark samples from wide areas, even without strong barriers. Further, this hypothesis has to be tested with samples from a wide distribution area sampled in as many intermediate points as possible. However, the identification of a moderate structuring among populations of Rhizoprionodon lalandii from the coast of São Paulo should be carefully appraised, because if this phenomenon is a rule for to be applied to this species, it will be very important to develop conservation politics for each of the units detected.

\section{Acknowledgements}

We would like to thank those who collaborated with the collection of Brazilian sharpnose shark, especially Fábio dos Santos Motta and Rafael Cabrera Namora, from Projeto Cação/ Itanhaém (UNESP - São Vicente); Carolina Bertozzi from Projeto Biopesca, Praia Grande, and Adilson Fransozo, from UNESP Botucatu. The authors also thank Fundação de Amparo à Pesquisa do Estado de São Paulo (FAPESP), Conselho Nacional de Desenvolvimento Científico e Tecnológico (CNPq), and Coordenação de Aperfeiçoamento de Pessoal de Nível Superior (Capes), for their financial support.

\section{Literature Cited}

Bonfil, R. 1994. Overview of world elasmobranch fisheries. FAO Technical Paper, 341: 119.

Camhi, M., S. Fowle, J. Musick \& F. S. Fordham. 1998. Sharks and their relatives. Occasional Paper of the IUCN Species Survival Commission, 20-39.

Cao, Y., P. J. Waddell, N. Okada \& M. Hasegawa. 1998. The complete mitochondrial DNA sequence of the shark Mustelus manazo: evaluating rooting contradictions to living bony vertebrates. Molecular Biology Evolutionary, 12: 1637-1646.

Compagno, L. J. V. 1984. Sharks of the world. An annotated and illustrated catalogue of shark species known to date. Food and Agriculture Organization of the United Nations, Rome. Carcharhiniformes. FAO Fish Synopisys, 4: 251-655.

Dunkan, K. M., A. P. Martin, B. W. Bowen \& H. G. De Couet. 2006. Global phylogeography of the scalloped hammerhead shark Sphyrna lewini. Molecular Ecology, 15: 2239-2251.
Excoffier, L. \& S. Schneider. 2005. Arlequin ver. 3.0: An integrated software package for population genetics data analysis. Evolution Bioinformatics, 1: 47-50.

Excoffier, L., P. E. Smouse \& J. M. Quattro. 1992. Analysis of molecular variance inferred from metric distances among DNA haplotypes: application to human mitochondrial DNA restriction data. Genetics, 131: 479-491.

FAO. 2002. FishStat PC. CD-Rom (Fisheries Information - Data and Statistic Unit, FAO Fisheries Department). Food and Agriculture Organization of the United Nations. Rome, 2002.

Figueiredo, J. L. 1977. Manual de peixes marinhos do sudeste do Brasil. I. Introdução. Cações, raias e quimeras. Museu de Zoologia - Universidade de São Paulo, 104p.

Gadig, O. B. F., F. S. Motta \& R. C. Namora. 2002. Projeto Cação - a study on small coastal sharks in São Paulo, southeast Brazil. Sustainable Management of Coastal Ecosystems Portugal, 239-246.

Grace, M. \& T. Henhwood. 1997. Assessment of the distribution and abundance of coastal sharks in the U. S. Gulf of Mexico and Eastern Seabord. Marine Fish, 59: 23-32.

Heist, E. J., J. E. Graves \& J. A. Musick. 1995. Population genetics of thesandbar shark Carcharhinus plumbeus in the Gulf of Mexico andmid-Atlantic Bight. Copeia, 1995(3): 555-562.

Heist, E. J., J. A. Musick \& J. E. Graves. 1996. Mitochondrial DNA diversity and divergence among sharpnose sharks, Rhizoprionodon terraenovae, from the Gulf of Mexico and midAtlantic Bight. Fishering Bulletin, 94: 664-668.

Kasim, H. M. 1991. Shark fishery of Veraval coast with special reference to population dynamics of Scoliodon laticaudus Müller and Henle and Rhizoprionodon acutus Ruppell. Journal Marine Biology Association, 33: 213-228.

Keeney, D. B., M. R. Heupel, R. E. Hueter \& E. J. Heist. 2005. Microsatellite and mitochondrial DNA analyses of the genetic structure of blacktip shark (Carcharhinus limbatus) nurseries in the north western Atlantic, Gulf of Mexico, and Caribbean Sea. Molecular Ecology, 14, 1911-1923.

Lessa, R. P. T. 1986. Contribuição ao conhecimento da biologia de Carcharhinus porosus Ranzani, Pisces, Chondrichthyes das reentrâncias maranhenses. Acta Amazonica, 16/17: 73-86.

Motta, F. S., O. B. F. Gadig, F. M. S. Braga \& R. C. Namora. 2005. Size and sex compositions, length-weight relationship, and occurrence of the Brazilian sharpnose shark, Rhizoprionodon lalandii, caught by artisanal fishery from southeastern Brazil. Fishering Research, 74: 116-126.

Nei, M. 1987. Molecular evolutionary genetics. New York, Columbia University Press, 39-46.

Sadowsky, V. 1967. Selachier aus dem litoral von São Paulo, Brazil. Beiträge zur Neotropischen Fauna, 5: 71-88.

Sambrook, J. \& D. W. Russell. 2001. Molecular Cloning: A Laboratory Manual. New York, ColdSpring Harbor Laboratory Press, Cold Spring Harbor, 2344p.

Stone, R. B., M. C. Bailey, S. A. McLaughlin, P. M. Mace \& M. B. Schulze. 1998. Federal Manegement of US Atlantic Shark fisheries. Fishering Research, 38: 215-221.

Stow, L. A., K. Zenger, D. Briscoe, M. Gillings, V. Peddemors, N. Otway \& R. Harcourt. 2006. Isolation and genetic diversity of endangered grey nurse shark (Carcharias taurus) populations. Biology Latters, 2: 308-311.

Xia, X. Z. 2001. DAMBE: Data analysis in molecular biology and evolution. Journal of Heredity, 92: 371-373.

Accepted April 2009 Published June 17, 2009 